\title{
Female Reproductive Traits in a Population of the Pond Frog, Rana nigromaculata, with Prolonged Breeding Season
}

\author{
RYOHEI SHIMOYAMA
}

\begin{abstract}
Reproductive traits of female Rana nigromaculata inhabiting northern Ina Basin, Nagano Prefecture, were studied for two breeding seasons. The breeding season lasts at least two months between mid May and early July. This prolonged breeding is caused by markedly asynchronous development of ovarian eggs among females. Smaller females tend to breed later in the season than larger ones. Clutch size and ovum size are positively correlated with female snout-vent length.
\end{abstract}

Key words: Rana nigromaculata; Prolonged breeding; Ovarian development; Clutch size; Ovum size

Current studies on anuran mating behavior showed that duration of the breeding season is an important key to understand the mating systems. The duration of the breeding season has two main consequences. First, it determines male density at the breeding site, which often influences male mate-locating behavior. Second, arrival patterns of gravid females at the breeding sites differ markedly between species (or populations) with short breeding seasons and those with long breeding seasons (Wells, 1977; Arak, 1983). The arrival patterns of gravid females also strongly influence male mate-locating behavior (Wells, 1977). Based on the duration of the breeding season, anuran breeding patterns are divided into two major categories. One is explosive breeding in which breeding activities occur within a few weeks, and the other is prolonged breeding in which breeding activities extend for more than a month (Wells, 1977).

In order to understand fully the mating system of a given population of anurans, exact duration of the breeding season should be clarified with relation to the arrival pattern of gravid females. It is, however, relatively difficult to observe the temporal pattern of appearance of gravid females in species which inhabit exclusively their breeding sites, because reproductive and nonreproductive females always coexist there. In such species, investigation of the female ovarian cycle is a useful method to learn the temporal pattern of female reproduction (Serizawa, 1985).

Rana nigromaculata is a common pond frog distributed widely in east Asian regions, including China, Korea, and Japan (Maeda and

Accepted 1 May 1993
Matsui, 1989). It lives around paddy fields of plains and hillsides, and breeds from spring to early summer in still waters such as paddy fields and ponds. Breeding habits of this frog have been noted by numerous investigators (e.g., Liu, 1931; Kokuryo, 1979; Serizawa, 1983), and it has been regarded as an explosive breeder (see also Wells, 1977: Appendix 4). However, in the northern Ina Basin, Nagano Prefecture, breeding activities of $R$. nigromaculata, that is, male displays and deposition of eggs, can be observed for a long period from mid May to early July. The purpose of the present study was to learn the proximate cause of such prolonged breeding in this population. In the present paper, I report temporal changes in female reproductive conditions and some clutch parameters based on data for two breeding seasons.

\section{Study SITE AND Methods}

This study was carried out in the breeding seasons of 1985 and 1989 in paddy fields of ca. 3 ha in Tatsuno $\left(35^{\circ} 56^{\prime} \mathrm{N}, 137^{\circ} 58^{\prime} \mathrm{E}, 750 \mathrm{~m}\right.$ above sea level), Nagano Prefecture, central Japan. The paddy fields were dry until late April, but were filled with water about $5 \mathrm{~cm}$ deep during late April-early September. Young rice plants were planted in mid May. The banks and paths along the paddy fields were partially covered with weeds and grasses.

Female pond frogs were sought and collected once every 15 days from mid May to late July. But I failed to capture females in late July in both years. Individuals which were obviously immature, i.e., less than about $50 \mathrm{~mm}$, were not captured. All individuals captured were fixed in $10 \%$ formalin solution within the day of cap- 
ture. They were preserved for about a month, and then were measured for snout-vent length (SVL) and dissected. Reproductive conditions of individual females were classified into five stages based on the degree of egg development in their ovaries or oviducts, i.e., I: undeveloped ovaries; II: developing ovaries; III: ovaries with well-developed eggs; III': oviductal eggs; IV: after spawning (see Serizawa, 1983 for details). Females whose ovaries were in stages II-IV were judged to be sexually mature and those whose ovaries were in stage I were judged to be juveniles. As to the females of stages III and III', the number of eggs within the ovaries or oviducts was counted directly, and the total number of eggs per female was regarded as clutch size. In addition, 10 eggs each from the females of stage III' were picked at random from the oviducts and their diameter was measured to the nearest $0.1 \mathrm{~mm}$ with an ocular micrometer. The average diameter of the 10 eggs is referred to as the ovum size for each female.

\section{RESULTS}

The pond frogs were not found before 10 May even if the paddy fields were already filled with water ca. $5 \mathrm{~cm}$ deep. The first capture of mature females was made on 12 May in 1985 and on 14 May in 1989. Male displays, including calling and territorial behavior, and newly deposited egg masses were observed from the emergence until early July in both years. But as I did not observe any actual oviposition, the mothers of the egg masses could not be identified.

Temporal changes in female reproductive conditions in 1985 and 1989 are shown in Figures 1

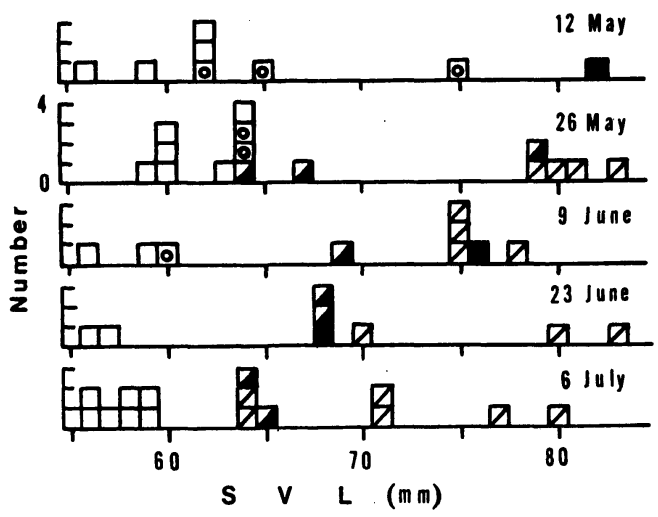

Fig. 1. Reproductive conditions of females in 1985. Each square represents one individual; open=stage I; with open circle=stage II; semisolid = stage III; solid = stage III'; with an oblique line $=$ stage IV.

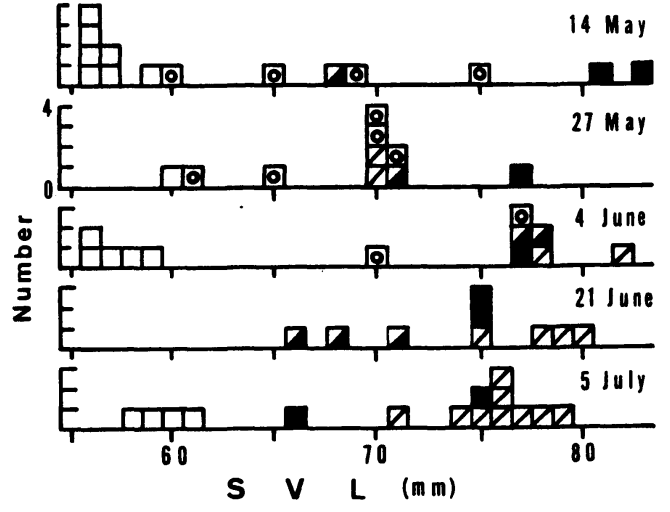

FIG. 2. Reproductive conditions of females in 1989. Refer to Fig. 1 for explanation of symbols.

and 2, respectively. In both years, there was a remarkable variation in the reproductive conditions among mature females. For example, three of four mature females (75.0\%) captured on 12 May 1985 had developing oocytes in their ovaries (stage II), whereas a large female (25.0\%) already had oviductal eggs (stage III'). Likewise, at least two reproductive stages were observed in mature females on each capture. Figure 3 shows the relationship between day of observation and SVL of the smallest breeding females, i.e., those after ovulation. There was a trend for smaller females to breed later in the season than larger ones (1985: Kendall's tau $=-1.0, \mathrm{p}<0.01 ; 1989$ : tau $=-0.60, \mathrm{p}=$ 0.117). Some small females still had well-developed eggs in their ovaries or oviducts in early July. Thus the period of ovulation lasted at least two months between mid May and early July in both years. The smallest size of the mature female was $60.0 \mathrm{~mm}$ in SVL. No female had

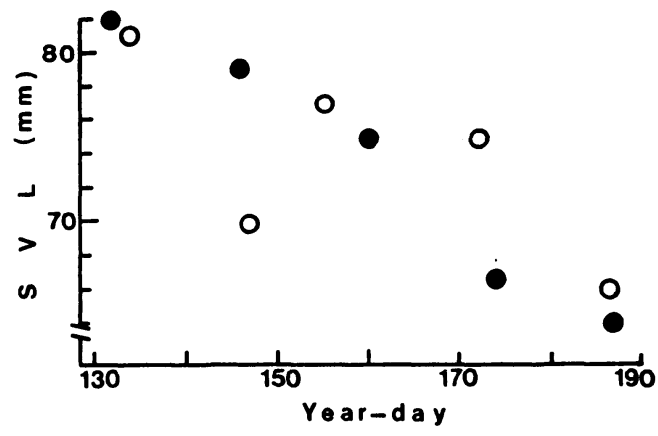

Fig. 3. Relationship between day of year $(1=1$ January) and SVL of the smallest breeding female. Females in reproductive conditions III'-IV were regarded to be breeding animals. Closed circles: 1985, open circles: 1989. 


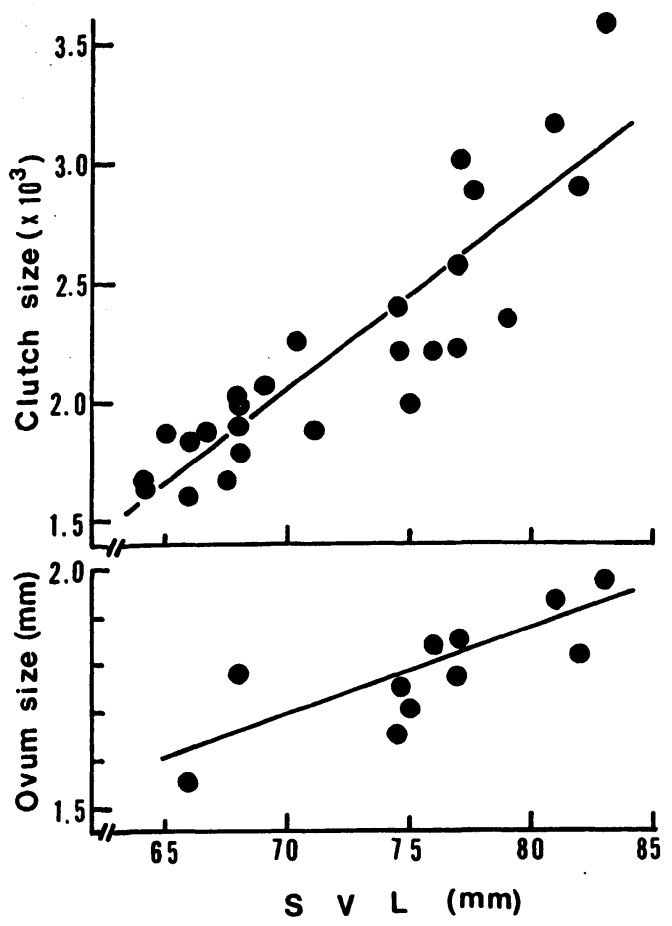

Fig. 4. Correlation between SVL and clutch size (A) and between SVL and ovum size (B). The regression equations are $Y=76.5 X-3310.6$ (A) and $\mathrm{Y}=0.018 \mathrm{X}+0.433(\mathrm{~B})$.

ovaries with redeveloping oocytes during this study.

Figure 4 shows the relationship between female SVL and clutch size (A) and that between SVL and ovum size (B). Data for the two seasons were pooled. Clutch size varied among individuals ranging from 1597 to 3556 $(\bar{x}=2206.4, \quad S D=510.15, \quad N=26), \quad$ and was positively correlated with SVL $(r=0.884$, $\mathrm{p}<0.001)$. On the other hand, ovum size varied from 1.55 to $1.97 \mathrm{~mm}(\bar{x}=1.78 \mathrm{~mm}, \mathrm{SD}=0.121$, $\mathrm{N}=11$ ), and was also positively correlated with SVL $(r=0.781, p<0.005)$. There was a significant positive correlation between ovum size and clutch size $(r=0.800, p<0.005, N=11)$.

\section{Discussion}

This study showed female reproductive traits of Rana nigromaculata inhabiting northern Ina Basin, Nagano Prefecture. The period in which ovulation and spawning occur lasted at least two months between mid May and early July in both years studied. Because male displays were also observed during this period, the breeding season in this population of $R$. nigromaculata was longer than two months. The prolonged breeding is caused by the asynchronous development of eggs among females. Reproductive conditions varied markedly among individuals, and smaller females tended to breed later in the season than larger ones (Figs. 1, 2). The asynchronous appearance of gravid females is one of the significant characteristics of anurans with prolonged breeding seasons (see Wells, 1977; Arak, 1983).

Previous studies on the breeding biology of $R$. nigromaculata showed that explosive breeding is the common breeding pattern in this frog (e.g., Liu, 1931; Kokuryo, 1979; Serizawa, 1983). In the populations of this frog with explosive breeding seasons, development of eggs is synchronous among individual females. For example, Serizawa (1983) showed that almost all mature females of this frog from Tatsuda, Aichi Prefecture, had well-developed ovarian eggs at the beginning of the breeding season. Under such conditions, spawning must occur synchronously within a relatively short period.

Serizawa $(1983,1985)$ suggested that shortage of water at the breeding sites is one possible factor which could cause extended duration of the breeding season. In my study site, however, the breeding sites, i.e., paddy fields, were already filled with enough water for breeding by late April when the pond frogs were still in hibernation, and the water depth was maintained until September. Therefore, it is unlikely that the timing and duration of the breeding activities were influenced by the water conditions in my population.

In some anuran species with prolonged breeding seasons, production of multiple clutches within a breeding season has been reported (e. g., Wells, 1976; Serizawa, 1983; Shimoyama, 1986). But as there were no females with redeveloping ovaries in this study, it was unlikely that females developed multiple clutches in a single breeding season. Therefore, it is considered that females spawn only one clutch during a breeding season as in the populations with explosive breeding seasons (e.g., Serizawa, 1983).

As shown in Figure 3, smaller females tended to breed later in the season. On the other hand, clutch size and ovum size were positively correlated with female SVL (Fig. 4), and therefore, ovum size was positively related to clutch size. These results indicate that smaller females have smaller and less numerous eggs than larger ones, and deposit the eggs later in the season.

Kuramoto (1978) showed a positive correlation between female body weight and both 
clutch size and ovum size in this frog from Fukuoka. According to Kuramoto, average clutch size and ovum size was 2113.6 and $1.80 \mathrm{~mm}$, respectively. These values are close to those of the present study. Serizawa et al. (1990) reported clutch size $(\bar{x}=2153)$ and ovum size $(\overline{\mathrm{x}}=1.95 \mathrm{~mm})$ in this frog from Tatsuda, and also showed a positive correlation between female SVL and clutch size (regression equation: Clutch size $=2.168 \mathrm{SVL}^{3.374}$ ). The regression equation shown by them is much larger than that of the present study, and may have some errors. Similarly, the average ovum size shown by them is markedly larger than those of Kuramoto (1978) and the present study. One of the possible causes of this difference is the difference in methodology of measuring ovum size (see Serizawa et al., 1990). There is also a possibility of occurrence of interpopulational variation in clutch parameters in this frog as known in Bufo japonicus (Matsui, 1989).

It has been pointed out that the temporal pattern of the availability of gravid females strongly affects the male mate-locating behavior and mating system in anurans (Wells, 1977; Arak, 1983). There is a possibility that the mating system of $R$. nigromaculata differs between populations with explosive breeding seasons and those with prolonged breeding seasons.

ACKNowledgments.- I thank Professor Toru Nakamura for providing the opportunity for this study in 1989. I also thank Dr. Masafumi Matsui for critical reading of an early draft of this paper and valuable comments.

\section{Literature Cited}

Arak, A. 1983. Male-male competition and mate choice in anuran amphibians. In: P. Bateson (ed.), Mate Choice. p. 181-210. Cambridge University Press, Cambridge.

KoKURYO, Y. 1979. Tonosama-gaeru (Rana nigromaculata). In: S. Sengoku (ed.), Amphibians and Reptiles in Color. p. 146-147. Ie no Hikari
Kyokai, Tokyo. (in Japanese)

KURAMOTo, M. 1978. Correlation of quantitative parameters of fecundity in amphibians. Evolution 32(2) : 287-296.

Liv, C. 1931. Sexual behavior in the Siberian toad, Bufo raddei and the pond frog, Rana nigromaculata. Peking Nat. Hist. Bull. $6: 43-60$.

Maeda, N. AND M. Matsui. 1989. Frogs and Toads of Japan. Bun-ichi Sogo Shuppan, Tokyo, 206 p. (in Japanese, with English abstract)

Matsui, M. 1989. Breeding strategy in the Japanese common toad, Bufo japonicus. In: M. Matsui, T. Hikida and R. C. Goris (eds.), Current Herpetology in East Asia. p. 332-341. Herpetol. Soc. Japan, Kyoto.

SERIZAWA, T. 1983. Reproductive traits of the Rana nigromaculata-brevipoda complex in Japan. I. Growth and egg-laying in Tatsuda and Saya, Aichi prefecture, Jpn. J. Herpetol. 10(1):7-19. (in Japanese, with English abstract)

SERIZAWA, T. 1985. Reproductive traits of the Rana nigromaculata-brevipoda complex in Japan. II. Egg-laying of Rana brevipoda brevipoda and $R$. nigromaculata in places dried up in early spring. Jpn. J. Herpetol. 11(1) : 11-19. (in Japanese, with English abstract)

Serizawa, T., Y. Tanigawa, and S. Serizawa. 1990. Reproductive traits of the Rana nigromaculata-porosa complex in Japan. IV. Clutch size and ovum size. Jpn. J. Herpetol. 13(3) : 80-86. (in Japanese, with English abstract)

SHMOYAMA, R. 1986. Maturity and clutch frequency of female Rana porosa brevipoda in the northern Ina basin, Nagano Prefecture, Japan. Jpn. J. Herpetol. 11(4) : 167-172.

WELLS, K. D. 1976. Multiple egg clutches in the green frog (Rana clamitans). Herpetologica 32(1) : 85-87.

WeLLS, K. D. 1977. The social behaviour of anuran amphibians. Anim. Behav. 25(3) : 666-693.

Laboratory of Animal Ecology, Joetsu University of Education, 1 Yamayashiki, Joetsu, Niigata, 943 JAPAN: Present address: Yonezawa Primary School, 4188 Yonezawa, Chino, Nagano, 391-02 JAPAN 
要旨 長期繁殖するトノサマガエル個体群にお

ける雌の繁殖特性について

\section{下山 良平}

長野県伊那谷北部に生息するトノサマガエル 倠の繁殖特性を，2シーズンにわたって調查し た. 繁殖期は， 5 月中旬から 7 月上旬にかけて の約 2 ケ月間に及んだ.こらした長期にわたる 繁殖は, 卵巣卵の発達状況が雌間で大きくばら ついていたために生じた。即の発達は小

さな雃ほど遅くなる傾向があった。一腹卵数と 卵サイズは，雌の頭胴長との間に正の相関があ った.

(943 上越市山屋敷町 1 上越教育大学動物 生態学研究室; 現在の所属 : 391-02 茅野市米 沢4188 米沢小学校) 